\title{
A New Paradigm on How to Write an Applied Bachelor Thesis
}

\author{
Nur Hasyim \\ \{hajinurhasim@gmail.com\} \\ Politeknik Negeri Jakarta, Indonesia
}

\begin{abstract}
This article describes a new way of writing genre-based applied bachelor's theses. The genre is a type of text, such as description, exposition, procedure, discussion. The study was conducted with qualitative research. Content analysis, interview, and participant observation is a method of data collection, while qualitative analysis is a method of data analysis. The result is that the author needs to know the writing needs of the part he is writing. The author needs to know what type of text is. The author needs to know the structure of writing the type of text along with linguistic features: conjunction, nouns, verbs, adjectives, adverbs, number words.
\end{abstract}

Keywords: Applied Bachelor Thesis, Genre, Vocational, Polytechnic

\section{Introduction}

Applied Bachelor's Thesis is a scientific paper that is prepared to fulfill one of the graduation requirements from the applied undergraduate level [1]. The old paradigm that is generally applied by students in writing an applied undergraduate thesis is to read the writing guide and then they immediately write. Students don't think about how to write an applied graduate thesis effectively. Because they do not use writing strategies, they often do not understand the writing objectives and often do not understand what should be written so that thesis writing often faces problems and often is not even finished. On the other hand, there is actually a writing strategy that can be used as a guideline in writing applied undergraduate theses, namely genre-based writing strategies. In this regard, in this regard, this article will describe the writing model of an applied undergraduate thesis based on genre.

\section{Method}

The study was conducted by conducting literature studies on various strategies for writing about applied undergraduate theses. Content analysis, interview, and participant observation is a method of data collection and the data of this study was be analyzed with qualitative analysis [2] that cited from Spreadly (1980): domain analysis, taxonomic analysis, inter-component analysis, and finding themes (concluding).

\section{Result and Discussion}

The National Seminar and Workshop Develops the Characteristics and Excellence of Applied Diploma III and Undergraduate Thesis Final Projects (2015) which are attended by Heads of Departments, Department Secretaries, and Heads of State Polytechnic Study Programs (Indonesia) defining applied theses as a thesis which contains applied research, which is (i) done to solve specific 
problems, practical questions related to product development to prototypes, (ii) done to answer questions about a particular problem or to make decisions or make decisions about a particular program or action or policy, (iii) designed to produce results that can be applied to real-world situations, (iv) are used to answer specific problems, determine why something can fail or succeed, solve certain pragmatic problems or to gain a better understanding, (v) examine the relationship and/or the application of theory or principle for problem solving, and usually done by consultants. This research was carried out on the basis of the need to solve problems in a particular organization.

Thesis organizational structure (applied bachelor) Accounting Department in accordance with the National Workshop and Seminar Develops Applied Characteristics and Excellence of Final Project Diploma III and Undergraduate Thesis (2015) as follows: (i) Cover page, (ii) Endorsement page and other pages, (iii) Table of contents , (iv) List of Tables, (iv) List of Figures, (v) List of Attachments, (vi) Abstract, (vii) Chapter I Introduction, (viii) Chapter II Literature Review, (ix) Chapter III Research Methods, (x) Chapter IV Description of Data and Discussion, (xi) Chapter V Closing: (a) Conclusions, and (b) Suggestions (recommendations), (xi) Bibliography (using the APA Method), and (xii) Attachments. Meanwhile, the organizational structure of the thesis (applied bachelor) Department of Business Administration is as follows: (i) front cover page, (ii) title page, (iii) page of originality statement, (iv) endorsement page, (v) abstract, (vi) preface, (vii) list of tables, (viii) list of tables, (ix) list of attachments, (x) list of symbols and abbreviations, (xi) Chapter I: Background, Problem Formulation, Problem Limitation, Goals, Problem Solving Methods, (xii) Chapter II Literature Review, (xiii) Chapter III Method and Settlement, (xiv) Chapter IV Results and Discussion, (xv) Chapter V Conclusions and Suggestions, (xvi) Literature List, and (xvii) Appendix.

In connection with the structure of scientific writing, Cargill and O'Connor stated that scientific writing consists of AIMRad: (i) Abstract, (ii) Introduction, (iii) Methods, (iii) Results, and Discussion. Thus, it can be stated that the thesis structure of the Accounting Department and the Polytechnic Administration Department is in line with the structure of the paper as presented by Cargill and O'Connor (2009).

Genre theory, among others, was delivered by [3] in his book entitled Working with Discourse, and (ii) Martin and Rose stated that genre is a staged goal-oriented social process (genre is a social process that is oriented towards goals that can be achieved gradually). Wiratno and Santosa state that text is a social process; Likewise, parts of the text are social processes. In certain social processes there are needs and targets that can be solved by using certain types of text because each particular type of text has linguistic characteristics so that when linguistic characteristics are understood and the social processes carried out are understood, the writing of texts can be carried out correctly and quickly.

Wiratno and Santosa said that thesis is a macro genre in which there are chapters, sub-sections, sub-sections, and other sections of the thesis. These parts are social processes so that the author can take advantage of the type of text / genre (in this case the micro genre), 1 type of text or more than 1 type of text, to achieve its purpose. To achieve this goal is carried out in stages / staged. The micro genres include (i) descriptions, (ii) reports, (iii) procedures, (iv) storytelling, (v) explanations, (vi) expositions, and (vii) discussions. The description is a type of text that describes what something is as it is (something as it is). The description text relates to the specificity of something described, its color, taste, and other physical properties. Report text is a type of text that deals with grouping things into classes or subclasses. In contrast to the description text which shows the specificity of something described, without comparing it with the others, the text of the report shows the generality of placing something reported into its class compared to the other classes. Procedure text is instructional text. In everyday life, the procedure text is found in the manual on how to operate electronic devices, how to call on the public telephone, and how to cook based on recipes. Storytelling is a text that contains activities or events that took place in the past. The social function is to arouse or revive real experiences in the past to create a kind of entertainment for the reader. Explanation text is a text that contains an explanation of the state of something as a result of something else that has happened before and caused something else to happen later. The social function of explanation is to explain the process of occurring something according to the principle of causation. Exposition text is a text that contains personal ideas or proposals about something. Exposition text is also called one-sided argumentation. Discussion text is a text that contains an issue or controversy about something. The issue was responded to from two sides of the argument so the discussion was often referred to as two- 
sided argumentation. In each type of text is built with the structure of the text and has certain linguistic characteristics.

Various types of text have linguistic characteristics. These linguistic characteristics are used as a reference for writing thesis sections (chapters, sub-sections, sub-sections, and other elements); the thesis sections are social processes that need to be written according to the appropriate genre / type of text.

Early research studies found no research on the development of thesis writing models (applied scholars), but found a number of articles that have investigated genres in the context of writing.

1. Loan and Pramoolsook in their research entitled "Move Analysis of Chapters ResultsDiscussion in Tesol Master's Theses Written by Vietnamese Students" published in 3L: The Southeast Asian Journal of English Language Studies - Vol 21 (2): 1 - 15 [4] found that nonnative English master students need to be given clear instructions on writing part of the research results and discussion: what parts are and how to write them.

2. Loan and Pramoolsook in his research entitled "Rhetorical Structure of Introduction Chapters written by Novice Vietnamese TESOL postgraduates" published in 3L: The Southeast Asian Journal of English Language Studies - Vol 20 (1): 61-74 [5] found that beginner writer needs to be given writing learning, clearer guidelines, genre and cultural knowledge.

3. Mashudi (2013) in his research entitled "Decentreness Factors and Communication Strategies in the Genre of Conversation on Television" published in the GEMA Online ${ }^{\circledR}$ Journal of Language Studies, 163 Volume 13 (3), September 2013, found that communication with regard to politeness would memorable.

4. Shabudin (2013) with his research entitled "Interdiskursiviti in the Discourse of Japanese Language Beauty Product Advertising" published in the GEMA Online ${ }^{\circledR}$ Journal of Language Studies 149 Volume 13 (2), May 2013 [6] found that in advertising discourse used descriptions of ingredients and function descriptions. Description of ingredients used in dermatology product discourse, while function descriptions are used in mask and eyelash product discourse.

5. Hyland in his article entitled "Genre Pedagogy: Language, Literacy, and L2 Writting Instruction" in the Journal of Second Language Writing (2007). Hyland said that genre could help students in writing so that writing is effective and relevant to their needs [7]. "For teacher educators, genre-based pedagogies offer a valuable resource for assisting both students and their students to produce effective and relevant texts." According to Hyaland, the genre is also very good for helping second language learning to be able to learn to write because the genre provides a clear explanation of the type of text.

6. Badger and White in his article entitled "A Process Genre Approach to Teaching Writting" in the Journal Language Teaching Research (2015). The article stated that there were three things that influenced the writing of writing: (i) a genre-based approach, (ii) the writing process, and (iii) written product. It was stated that the product of writing was determined by the process of writing and the genre approach [8]. Because of this, all three of these things influence each other.

7. Yasuda in his article entitled "Genre-based Tasks in Foreign Writting: Developing Writers" awareness genre, Linguistic Konowledge, and Writting Competence "in the Journal of Second Language Writting" (2011) [9] stated that "a combination of genres and task can create a crucial pedagogical link between socially written writing and language use, which is expected to create interfaces between writing and language development in FL contexts (a combination of genres and assignments can create crucial learning links between performance writing in certain social situations and language use choices that are expected to be able to provide the best work to create written work and language use in context. "

8. There are also studies related to writing scientific papers, but do not discuss the writing model of genre-based research methods [10]'

The genre-based model of Applied Bachelor's Thesis is designed to help polytechnic education students apply for undergraduate degrees so that they can write an Applied Bachelor's Thesis correctly and quickly. The paradigma writing based on genre as follows

1. the text is a social process; likewise the parts of the text are social processes, 
2. In certain social processes there are suitable needs and objectives when written using certain types of text.

3. Certain types of text have a text structure and linguistic characteristics, including verbs (processes) used, use of adjectives, and the use of conjunctions.

4. If certain parts of the Applied Bachelor's Thesis are written with the right type of text, writing will be done correctly and quickly.

5. Applied Bachelor's Thesis is a macro genre in which there are chapters, sub-chapters, subchapters, and other sections of the thesis.

6. These parts are social processes so that the author can utilize the type of text / genre (in this case is the micro genre), 1 type of text or more than 1 type of text, to achieve the goal

7. To achieve this goal is carried out in stages / staged.

8. Micro genre is (i) description, (ii) report, (iii) procedure, (iv) telling, (v) explanation, (vi) exposition, and (vii) discussion.

9. Text Description is a type of text that describes what something is as it is. The description text relates to the specificity of something described, its color, taste, and other physical properties.

10. Report text is a type of text that deals with grouping things into classes or subclasses. In contrast to the description text which shows the specificity of something described, without comparing it with the others, the text of the report shows the generality of placing something reported into its class compared to the other classes.

11. Procedure text is instructional text. In everyday life, the procedure text is found in the manual on how to operate electronic devices, how to call on the public telephone, and how to cook based on recipes.

12. Storytelling text is a text that contains activities or events that took place in the past. The social function is to arouse or revive real experiences in the past to create a kind of entertainment for the reader.

13. Explanation text is a text that contains an explanation of the state of something as a result of something else that had happened before and caused something else to happen later. The social function of explanation is to explain the process of occurring something according to the principle of causation.

14. Exposition text is a text that contains personal ideas or proposals about something. Exposition text is also called one-sided argumentation. Discussion text is a text that contains an issue or controversy about something. The issue was responded to from two sides of the argument so that the discussion was often called two-sided argumentation. In each type of text is built with the structure of the text and has certain linguistic characteristics.

15. Various types of text have linguistic characteristics. These linguistic features are used as a reference for writing thesis sections (chapters, sub-sections, sub-sections, and other elements. follows.

The paradigm of of writing an undergraduate thesis is applied essentially can make a chart, as

Chart: Paradigm of Write An Applied Bachelor Thesis

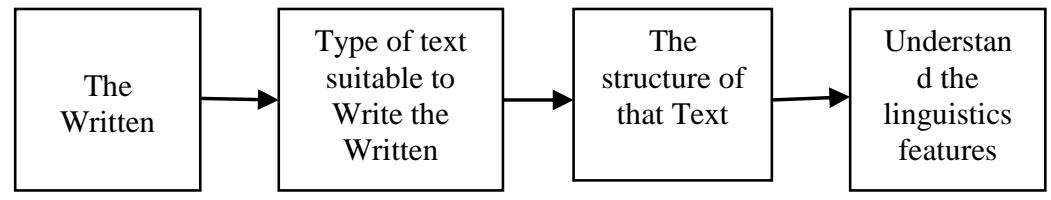

In another hand, we can explain that the new paradigm of writing an undergraduate thesis is applied essentially as follows. The author needs to know the writing needs of the part he is writing. The author needs to know what type of text is best used to write the part he is writing. The author needs to know the structure of writing the type of text along with the linguistic features he is writing. 


\section{Conclusion}

The new model of undergraduate thesis writing is applied based on understanding the mindset of writing. The mindset is as follows. First, the writer must be aware of what part he is writing. Second, the writer must know what must be written in part he is writing. Third, the writer needs to know what type of text is suitable for writing about what should be written. Fifth, the writer needs to know the structure of the text and the linguistic characteristics of the text he is writing.

\section{References}

[1] Politeknik Negeri Jakarta, Hasil Semiloka Nasional: Mengembangkan Keunggulan TA D III dan Skripsi Sarjana Terapan. Bogor, 2015.

[2] R. Santosa, Metode Penelitian Kualitatif Kebahasaan. Surakarta: UNS Press, 2017.

[3] D. Martin and Rose, Working with Discourse. london: Continum, 2007.

[4] Thi, N., Loan, T. and Pramoolsook, I. 'Move Analysis of Results-Discussion Chapters in TESOL Master 's Theses Written by Vietnamese Students', 21(2), pp. 1-15 (no date).

[5] Nguyen, T. T. L. and Pramoolsook, I. 'Rhetorical structure of Introduction chapters written by novice Vietnamese TESOL postgraduates', 3L: Language, Linguistics, Literature, 20(1), pp. 61-74. doi: 10.17576/3L-2014-2001-05 (2014).

[6] Shabudin. "Interdiskursiviti in the Discourse of Japanese Language Beauty Product Advertising" published in the GEMA Online ${ }^{\circledR}$ Journal of Language Studies 149 Volume 13 (2), (May 2013).

[7] Hyland in his article entitled "Genre Pedagogy: Language, Literacy, and L2 Writting Instruction" in the Journal of Second Language Writing (2007). .

[8] Badger and White in his article entitled "A Process Genre Approach to Teaching Writting" in the Journal Language Teaching Research (2015). .

[9] Yasuda in his article entitled "Genre-based Tasks in Foreign Writting: Developing Writers" awareness genre, Linguistic Konowledge, and Writting Competence "in the Journal of Second Language Writting" (2011). .

[10] W. Yang, "Genre Analysis of Dissertation Acknowledgements : A Comparative Study across Contexts," vol. 19, no. 2, pp. 27-40, (2004). 